\title{
Some Properties of Astronium graveolens Wood Along the Stem
}

\author{
Eduardo Luiz Longui ${ }^{1}$, Cássia Christine Schmidt Gondo ${ }^{1}$, Israel Luiz de Lima ${ }^{1}$, \\ Miguel Luiz Menezes Freitas ${ }^{2}$, Sandra Monteiro Borges Florsheim ${ }^{1}$, \\ Antonio Carlos Scatena Zanatto ${ }^{3}$, José Nivaldo Garcia ${ }^{4}$ \\ ${ }^{1}$ Divisão de Dasonomia, Seção de Madeira e Produtos Florestais, Instituto Florestal, São Paulo/SP, Brazil \\ ${ }^{2}$ Seção de Melhoramento Florestal, Instituto Florestal, São Paulo/SP, Brazil \\ ${ }^{3}$ Divisão de Florestas e Estações Experimentais, Instituto Florestal, Luiz Antonio/SP, Brazil \\ ${ }^{4}$ Departamento de Ciências Florestais, Escola Superior de Agricultura Luiz de Queiróz - ESALQ, \\ Universidade de São Paulo - USP, Piracicaba/SP, Brazil
}

\begin{abstract}
We investigated the axial variation of specific gravity, shear parallel to the grain and anatomical features of Astronium graveolens wood and related these properties to the anatomy along the stem. We felled five 20-year-old trees and cut discs from four different stem heights, including stem base, 1 meter, 2 meters and 3 meters, for a total of 20 discs, and studied wood samples near the bark and at the base of trunk. Axial variations found appear to provide a balance between mechanical strength of the wood at stem base by the higher density and higher shear by the increase in ray frequency that contributes to locking the vertical cells and growth rings, thus preventing the stem from easily breaking when bent. For hydraulic conductivity, vessels with smaller diameter and frequency at the stem base help prevent the occurrence of embolisms that would reduce water flow along the main stem.
\end{abstract}

Keywords: hydraulic conductivity, strength of wood, guaritá, axial variation.

\section{Algumas Propriedades da Madeira de Astronium graveolens ao Longo do Caule}

\section{RESUMO}

Determinamos as variações axiais da densidade aparente, resistência ao cisalhamento paralelo à grã e anatomia da madeira de Astronium graveolens, relacionando estas propriedades ao longo do fuste. Cortamos cinco árvores com 20 anos de idade e estudamos amostras próximas da casca na base do tronco, a um, dois e três metros de altura. As variações axiais encontradas no lenho de A. graveolens parecem propiciar um equilíbrio entre a resistência mecânica da madeira na base do fuste pela maior densidade e também pela maior resistência ao cisalhamento devido a maior frequência de raios que contribuem no travamento das células orientadas no sentido vertical evitando assim que o tronco quebre facilmente ao ser flexionado. Pensando na condutividade hidráulica, vasos com menor diâmetro e frequência na base do fuste podem garantir maior segurança ao diminuir a ocorrência de embolismos que poderiam prejudicar o fluxo de água ao longo do fuste.

Palavras-chave: condutividade hidráulica, resistência da madeira, guaritá, variação axial. 


\section{INTRODUCTION}

Astronium graveolens Jacq. - Anarcadiaceae (guaritá), a native, but not endemic, species of Brazil, is distributed in all regions of the country, occurring in four southeastern states. A. graveolens occurs naturally in the Amazon, Caatinga, Savannah, Atlantic Forest and Pampa in cultivated areas and in different vegetation types: Savannah, Gallery Forest, Semideciduous Forest and Rain Forest (Silva-Luz \& Pirani, 2013). Adult trees with a trunk diameter of 40-60 cm can reach 15-25 meters in height. Its wood is heavy (specific gravity $970 \mathrm{~kg} \mathrm{~m}^{-3}$ ), hard to cut, and has long durability; its heartwood displays a uniform color and is well differentiated from the sapwood (Lorenzi, 2002).

The concern over the genetic conservation of this species has been highlighted for more than 20 years by Siqueira \& Nogueira (1992). In ecological terms, studies on the population dynamics of $A$. graveolens show that terrain slope influences the spatial distribution of trees (Pavanelli et al., 2011). Also, studies on the seedlings distribution have shown that new trees could not be established within a radius of $20 \mathrm{~m}$ from the mother plant (Durigan, 1992). Hernández et al. (2013) characterized the chemical constituents of $A$. graveolens and showed that the essential oil of its aerial parts exhibits strong antibacterial activity. Associated with the wood use, the authors suggested that the removal of oils from the leaves could add value to the timber industry.

Studies of the wood anatomy of A. graveolens include the most recent work of Woodcock (1994). Studying 66 species of trees in a tropical dry forest in Costa Rica, this author found variation in vessel diameter within the growth layers in many of them, including A. graveolens, a feature not noted in our previous work (Santos et al., 2011). In addition, Tomazello-Filho et al. (2004) studied growth rings in 41 tree species and found that the growth rings of A. graveolens are scarcely distinct.

Using the same trees investigated in the present study, Santos et al. (2011) reported on A. graveolens wood at breast height (DBH) over 20 years of age in a homogeneous plantation. This wood showed no radial variation in basic density. Moreover, the anatomical features, generally suggested that this species, under these growing conditions, must maintain homogeneity and quality, independent of the cut tree. It was concluded that the radial variations and correlations between density and anatomical features of the wood analyzed must have resulted from the growth and cambium maturation in a manner that allows for a balance between water conduction and mechanical strength. To expand the study of Santos et al. (2011), we examine here the axial variation of some properties and anatomy in the same plants to determine the axial variation of specific gravity, shear parallel to the grain and anatomical features of Astronium graveolens wood and relate these properties to the anatomy along the stem.

\section{MATERIAL AND METHODS}

We sampled five 20-year-old Astronium graveolens trees (Table 1) from Luiz Antônio Experimental Station,

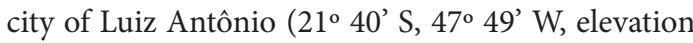
$550 \mathrm{~m}$ ), São Paulo State. The plantation was established in 1990 at a spacing of $3 \mathrm{~m} \times 3 \mathrm{~m}$. In 2010, we felled trees and cut discs from four different stem heights: stem base, 1 meter, 2 meters and 3 meters, for a total of 20 discs. For standardization in all samples, we studied wood near the bark, always on the same side of the stem marked by magnetic north (Figure 1).

Table 1. Dendrometric data of 20-year-old Astronium graveolens wood from base to three meters of the stem.

Tabela 1. Dados dendrométricos da madeira de Astronium graveolens aos 20 anos de idade da base aos três metros do fuste.

\begin{tabular}{cccccc} 
Tree & $\begin{array}{c}\text { Diameter stem } \\
\text { base }(\mathbf{c m})\end{array}$ & $\begin{array}{c}\text { Diameter } \mathbf{1} \mathbf{~ m} \\
(\mathbf{c m})\end{array}$ & $\begin{array}{c}\text { Diameter } \mathbf{~} \mathbf{~ m} \\
(\mathbf{c m})\end{array}$ & $\begin{array}{c}\text { Diameter } \mathbf{3} \mathbf{~ m} \\
(\mathbf{c m})\end{array}$ & $\begin{array}{c}\text { Height } \\
(\mathbf{m})\end{array}$ \\
\hline 1 & 18.8 & 14.7 & 13.4 & 12.5 & 14.7 \\
2 & 19.9 & 14.8 & 12.7 & 12.2 & 14.1 \\
\hline 3 & 21.3 & 17.2 & 16.5 & 14.4 & 15.7 \\
\hline 4 & 20.3 & 14.3 & 12.7 & 11.9 & 12.9 \\
\hline 5 & 21.9 & 17.0 & 15.6 & 14.1 & 15.0 \\
\hline
\end{tabular}




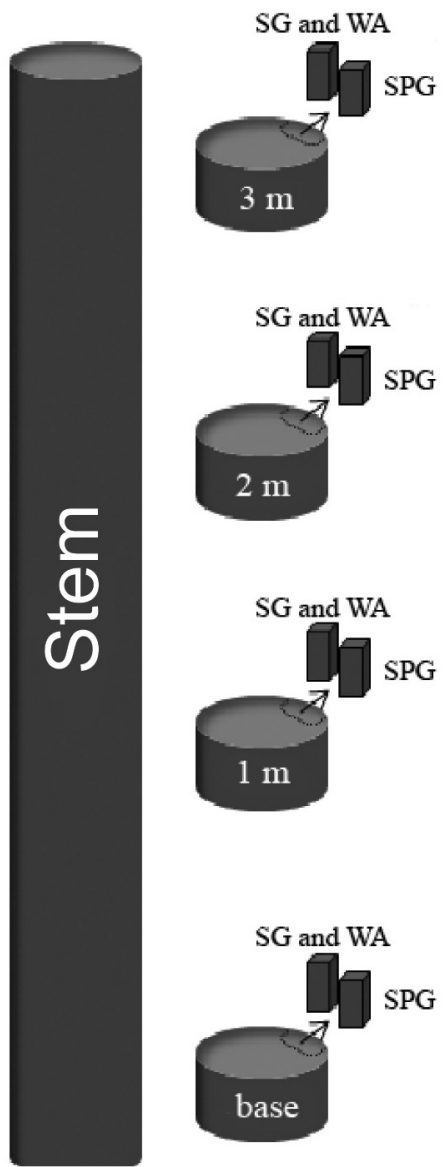

Figure 1. Sampling for specific gravity (SG) wood anatomy (WA) and shear parallel to the grain (SPG).

Figura 1. Amostragem para densidade aparente (SG) anatomia da madeira (WA) e resistência ao cisalhamento paralelo à grã (SPG).

Specific gravity was determined according to Glass \& Zelinka (2010). Samples of $2 \times 2 \times 3 \mathrm{~cm}$ were dried at standard temperature to reach about $12 \%$ moisture content. Then, the oven-dried mass and volume samples displaced by immersion in water were determined with semi-analytical balance.

The same samples used in the specific gravity determination were used for anatomical analysis. Small portions of wood from each sample were macerated using Franklin's method (Berlyn \& Miksche 1976, modified), stained with aqueous safranin and mounted temporarily in a solution of water and glycerin (1:1). Samples of $1.5 \mathrm{~cm}^{3}$ were softened in boiling water and glycerin (4:1) for 1 hour. From these samples, transverse and longitudinal sections of $18-25 \mu \mathrm{m}$ in thickness were obtained with a sliding microtome. Sections were bleached with sodium hypochlorite (60\%), washed thoroughly in water, and stained with $1 \%$ safranin (Johansen, 1940). Measurements followed the recommendations of the IAWA Committee (IAWA, 1989). Quantitative data are based on at least 25 measurements for each feature from each tree, thus fulfilling statistical requirements for minimum numbers of measurements.

Shear parallel to the grain was determined with samples of $2 \times 2 \times 3 \mathrm{~cm}$ with $5 \mathrm{~cm}^{2}$ shear area. At one end was a characteristic cut of the shear samples (ASTM, 2005-2006). The samples had previously been measured with a caliper to determine the areas of each sample (12\%, moisture). The load application spped was $2.5 \mathrm{MPa}\left(\mathrm{N} \mathrm{mm}^{-2} \mathrm{~min}^{-1}\right)$.

We initially performed descriptive statistical analysis considering all axial positions. We performed the Normality Test to observe the data distribution. Based on the normal data distribution, a parametric analysis of variance (One Way Analysis of Variance) was performed. When a significant difference was observed, we employed the Tukey test to identify pairs of significantly different means. Results with $\mathrm{p}<0.05$ were considered significant.

\section{RESULTS AND DISCUSSION}

Specific gravity was higher at the base and did not differ among others positions (Figure 2a). Shear showed no significant difference in any analyzed heights (Figure 2b).

Fiber wall thickness did not differ along the stem (Figure 3a). Longer fibers occurred at $2 \mathrm{~m}$ and shorter fibers at the base. The one and three meter positions did not differ (Figure 3b).

Vessel diameter was wider at 3 meters, and vessel frequency was higher at 2 meters. Both traits were reduced at the base (Figure $4 \mathrm{a}, \mathrm{b}$ and Figures $5 \mathrm{a}, \mathrm{b}$ ).

Rays height and width did not vary along the stem, but the frequency was higher at the base (Figures 6a-c).

A negative relationship was observed between specific gravity and vessel diameter, and a positive relationship was noted between shear parallel to the grain and ray frequency (Figures $7 \mathrm{a}, \mathrm{b}$ ).

Higher specific gravity at the stem base could, in part, be explained by a lower vessel frequency and 

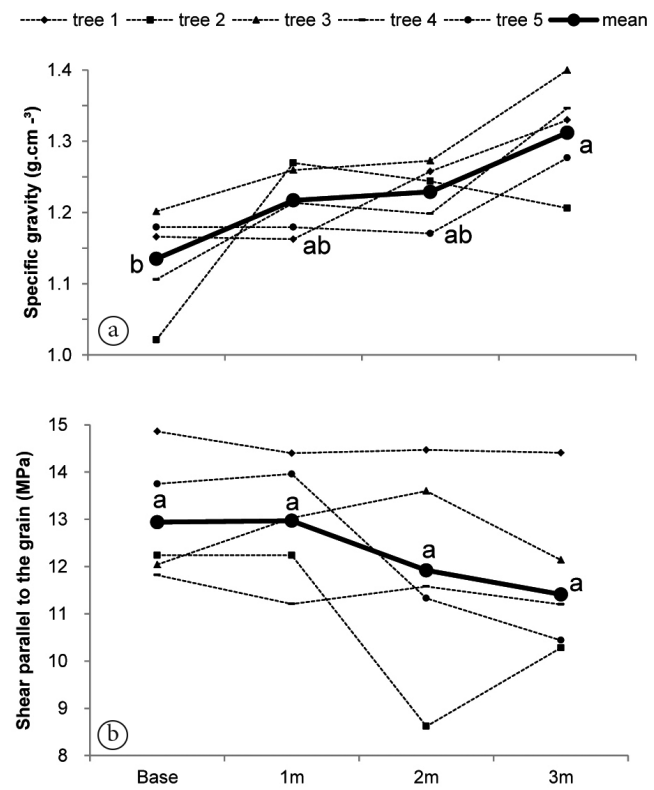

Figure 2. Axial variation of specific gravity (a) and shear parallel to the grain (b) in Astronium graveolens wood. Different letters show significant statistical variation ( $\mathrm{P}<0.05$ by Tukey's test $)$.

Figura 2. Variação axial da densidade aparente (a) e resistência ao cisalhamento paralelo à grã (b) na madeira de Astronium graveolens. Letras diferentes mostram variação estatística $(\mathrm{P}<0.05$ pelo teste de Tukey).
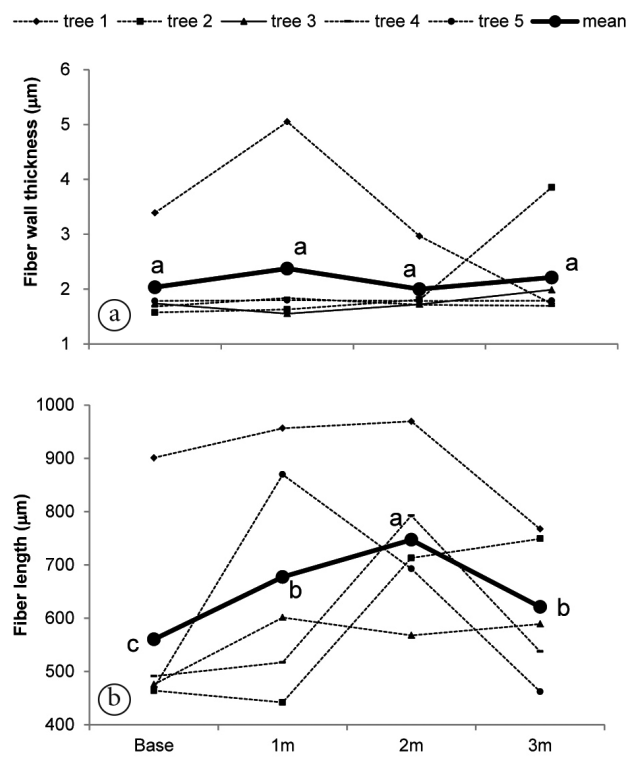

Figure 3. Axial variation of fiber wall thickness (a) and fiber length (b) in Astronium graveolens wood. Different letters show the significant statistical variation $(\mathrm{P}<0.05$ by Tukey's test).

Figura 3. Variação axial da espessura da parede das fibras(a) e comprimento das fibras (b) na madeira de Astronium graveolens. Letras diferentes mostram variação estatística $(\mathrm{P}<0.05$ pelo teste de Tukey).
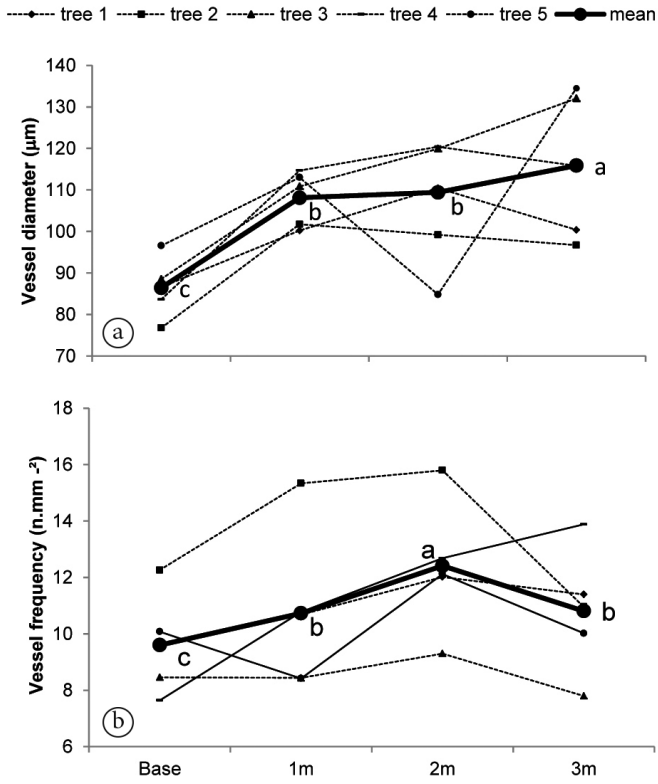

Figure 4. Axial variation of vessel diameter (a) and vessel frequency (b) in Astronium graveolens wood. Different letters show the significant statistical variation $(\mathrm{P}<0.05$ by Tukey's test $)$.

Figura 4. Variação axial no diâmetro dos vasos (a) e na frequência dos vasos (b) na madeira de Astronium graveolens. Letras diferentes mostram variação estatística $(\mathrm{P}<0.05$ pelo teste de Tukey).

especially by smaller vessel diameters, as seen in the negative relationship between specific gravity and conduit diameter (Figure 7), a phenomenon which has also been reported in other studies (Fan et al., 2012; Martínez-Cabrera et al., 2011). As reported by Gartner (1995), the pattern of xylem density from the base to the top of stem depends mainly, but not always entirely, on the pattern found from pith to bark, essentially because the vertical profile reflects the simultaneous production of outer wood at the base, if a plant is old enough, and core wood at the top. However, we emphasize that our study was performed with near-bark samples, and according to the most commonly found radial patterns, the vessel diameter increases toward the bark since a mature cambium can produce cells with larger dimensions (Baas et al., 2004; Lachenbruch et al., 2011). Thus, according to the literature, the presence of vessels with a larger diameter was found at the base, as expected, because the cambium would be more mature in this region. In fact, the increase in vessel diameter and decrease in frequency occurred in the 




Figure 5. Transverse sections of Astronium graveolens wood. Three meter position (a); Base position (b). Note the smaller vessel diameter at the base compared with that at three meters. Scale bars $=500 \mu \mathrm{m}$.

Figura 5. Secções transversais da madeira de Astronium graveolens. Aos três metros de altura (a); $\mathrm{Na}$ base do caule (b). Notar vasos de menor diâmetro na base do caule quando comparados com aqueles aos três metros de altura. Barras de escala $=500 \mu \mathrm{m}$.

radial direction in these same trees previously studied by our group (Santos et al., 2011), However, sampling was performed at breast height (DBH), which has other mechanical requirements when compared with the base of the stem that we investigated in this study.

As in other studies from our group with different species, including Anadenanthera peregrina, Copaifera langsdorffi, Handroanthus ochraceus, Handroanthus vellosoi, Ocotea corymbosa and Xylopia aromatica (in press), we noted vessels with smaller diameters in the stem base, which we attribute to the maintenance of water transport in the main trunk hydraulic system. Specifically, vessels with smaller diameters have lower water conduction requirements than vessels of larger diameters, and smaller conduits provide less risk of embolism (Tyree \& Zimmermann, 2002). Moreover,
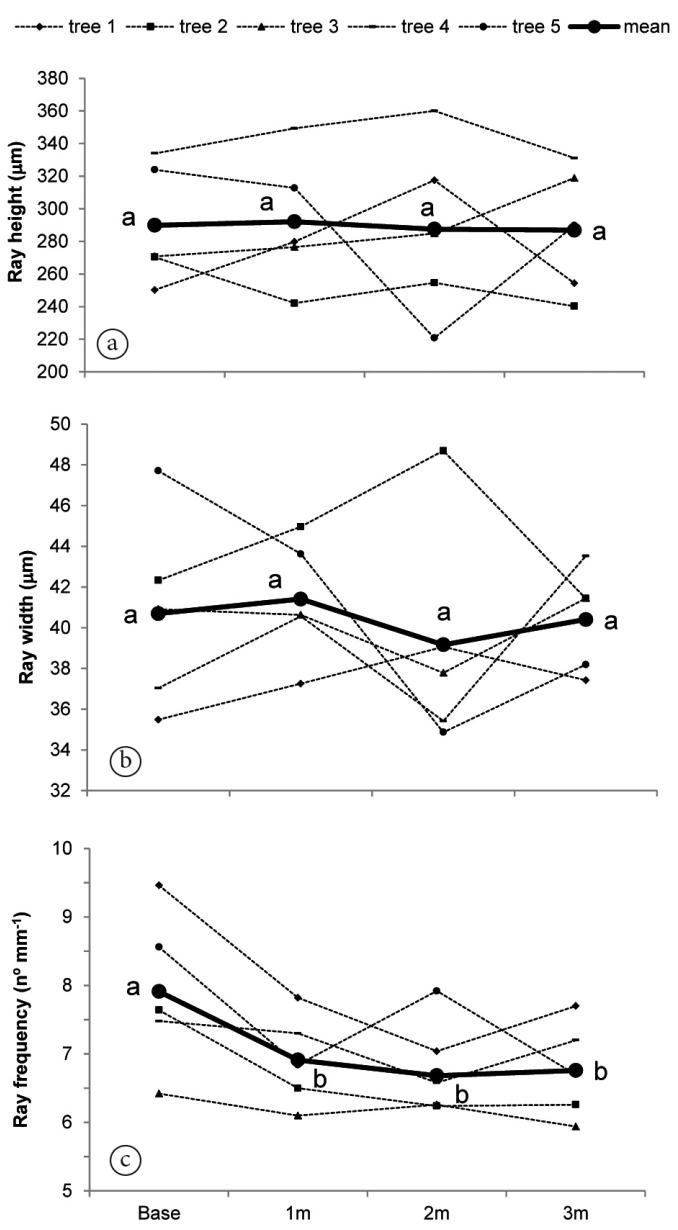

Figure 6. Axial variation of ray height (a), ray width (b) and ray frequency (c) in Astronium graveolens wood. Different letters show the significant statistical variation ( $\mathrm{P}<0.05$ by Tukey's test).

Figura 6. Variação axial da altura dos raios (a), largura dos raios (b) e frequência dos raios (c) na madeira de Astronium graveolens. Letras diferentes mostram variação estatística $(\mathrm{P}<0.05$ pelo teste de Tukey).

vessel diameter may be related to the biomechanical requirements of tree support to accommodate the self-weight of stem and crown (Niklas, 1992). Under these circumstances, larger and more frequent vessels would negatively impact wood density (Hoadley, 2000; Fan et al., 2012; Martínez-Cabrera et al., 2011). Since density is a good indicator of mechanical properties (Glass \& Zelinka, 2010; Kretschmann, 2010), higher values in the base would have a positive impact on the strength of the tree.

In association with smaller vessel diameters at the stem base, we highlight that ray frequency was higher 

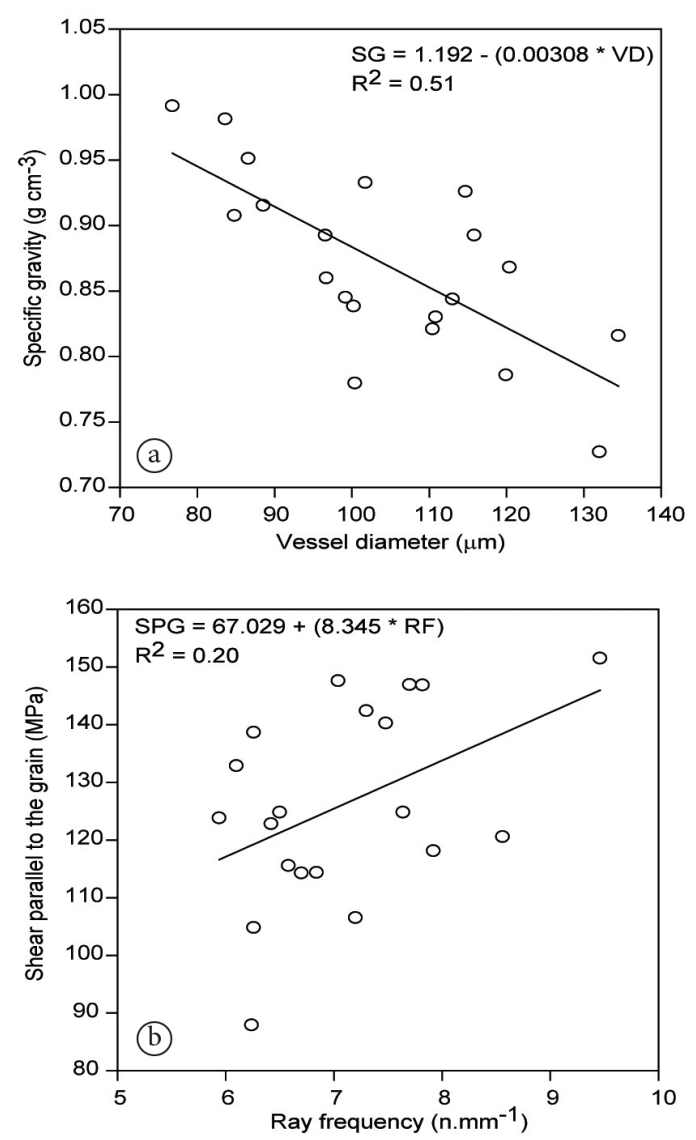

Figure 7. Linear regressions between properties and anatomy of Astronium graveolens wood: specific gravity as a function of vessel diameter (a); shear parallel to the grain as a function of ray frequency (b).

Figura 7. Regressões lineares entre propriedades e anatomia na madeira de Astronium graveolens: densidade aparente em função do diâmetro dos vasos (a); resistência ao cisalhamento paralelo à grã em função da frequência de raios (b).

in this region (Figure 6) and that this result appears to have an important effect on shear strength, as noted in Figure 7. In structural terms, the stem base wood is denser and more resistant to shearing, i.e., slipping or breakage of the cells by the effect of strong winds which could bend the tree stem. The structural role of rays in the resistance of wood has been demonstrated in other studies (Mattheck \& Kubler, 1997; Burgert \& Eckstein, 2001; Reiterer et al., 2002).

Although fibers present a noticeable effect on wood support in A. graveolens, these cells do not appear to impact the biomechanical changes, in particular, since the fiber wall thickness did not vary between the axial positions (Figure 3). We noticed longer cells in $2 \mathrm{~m}$ of the stem, which apparently produce no significant effect on support. Shorter fibers were observed in the stem base. Since this common pattern of radial variation has already been described by Lachenbruch et al. (2011), we expected longer fibers at the base because of the greater cambium maturity, a result found in our other study with the same samples measured at DBH (Santos et al., 2011). Kiaei \& Samariha (2011) showed negative relationships between the fiber length and such properties as modulus of rupture, modulus of elasticity and compression parallel to the grain in five hardwood plants: Quercus castaneaefolia, Fagus orientalis, Carpinus betulus, Alnus glutinosa and Fraxinus excelsior. Our hypothesis is that shorter fibers in the base can also positively impact the mechanical strength of the stem in A. graveolens.

Both the radial variation values mentioned by Santos et al. (2011) and the axial variations highlighted in the present study are important because they represent the characteristics of trees with age, origin, known spacing that developed in homogeneous plantation and can thus be used as a reference for the species at 20 years of age.

\section{CONCLUSIONS}

The axial variations found in Astronium graveolens wood appear to provide a balance between the mechanical strength of the wood at stem base by the higher density and the higher shear by the increase in ray frequency that contributes to locking the vertical cells and growth rings, thus preventing the stem from easily breaking when bent. For hydraulic conductivity, vessels with smaller diameter and frequency at the stem base can help prevent the occurrence of embolisms that would reduce water flow along the main stem.

\section{ACKNOWLEDGEMENTS}

The authors thank Sonia Regina Godói Campião and Camila Paro for laboratory assistance.

\section{SUBMISSION STATUS}

Received: 21 aug., 2014

Accepted: 12 aug., 2015 


\section{CORRESPONDENCE TO}

\section{Eduardo Luiz Longui}

Divisão de Dasonomia, Seção de Madeira e

Produtos Florestais, Instituto Florestal, Rua do

Horto, 931, Horto Florestal, CEP 02377-000, São

Paulo, SP, Brazil

e-mail: edulongui@gmail.com

\section{REFERENCES}

American Society for Testing and Materials - ASTM. Annual Book of ASTM Standards: standard 143-83. West Conshohocken; 2005-2006. vol. 4.10.

Baas P, Ewers FW, Davis SD, Wheeler EA. Evolution of xylem physiology. In: Poole I, Hemsley A, editors. Evolution of plant physiology. London: Elsevier Academic Press; 2004. p. 273-295. Linnaean Society Symposium Series.

Berlyn GP, Miksche JP. Botanical microtechnique and cytochemistry. Iowa: The Iowa University Press; 1976. 326 p.

Burgert I, Eckstein D. The tensile strength of isolated wood rays of beech (Fagus sylvatica L.) and its significance for the biomechanics of living trees. Trees 2001; 15(3): 168170. http://dx.doi.org/10.1007/s004680000086.

Durigan G. Distribuição espacial de plântulas de Astronium graveolens Jacq. (Anacardiacaea) em relação à árvore-mãe. Revista do Instituto Florestal 1992; 4(1): 207-211.

Fan ZX, Zhang SB, Hao GY, Ferry Slik JW, Cao KF. Hydraulic conductivity traits predict growth rates and adult stature of 40 Asian tropical tree species better than wood density. Journal of Ecology 2012; 100(3): 732-741. http://dx.doi.org/10.1111/j.1365-2745.2011.01939.x.

Gartner BL. Patterns of xylem variation within a tree and their hydraulic and mechanical consequences. In: Gartner BL, editors. Plant stems: physiology and functional morphology. New York: Academic Press; 1995. p. 125-149.

Glass S, Zelinka SL. Moisture relations and physical properties of wood. In: Ross R, editor. Wood Handbook. 100th ed. Madison: U.S. Department of Agriculture, Forest Service, Forest Products Laboratory; 2010. General Technical Report FPL-GTR-190.

Hernández V, Mora F, Araque M, Montijo S, Rojas L, Meléndez P, Tommasi N. Chemical composition and antibacterial activity of Astronium graveolens Jacq essential oil. Revista Latinoamerica Química 2013: 41(2): 89-94.

Hoadley B. Understanding wood: a craftsman's guide to wood technology. 2nd ed. Newtown: Taunton Press; 2000. 288 p.

International Association of Wood Anatomists - IAWA. List microscope features of hardwood identification. IAWA Bulletin 1989; 10(3): 219-332.
Johansen DA. Plant microtechnique. New York: McGrawHill; 1940. 533 p.

Kiaei M, Samariha A. Fiber dimensions, physical and mechanical properties of five important hardwood plants. Indian Journal of Science and Technology 2011; 4(11): 1460-1463.

Kretschmann DE. Mechanical properties of wood. In: Ross R, editor. Wood Handbook. 100th ed. Madison: U.S. Department of Agriculture, Forest Service, Forest Products Laboratory; 2010. General Technical Report FPL-GTR-190.

Lachenbruch B, Moore JR, Evans R. Radial variation in wood structure and function in woody plants, and hypotheses for its occurrence. In: Meinzer FC, Lanchenbruch B, Dawson TE, editors. Size-and age-related changes in tree structure and function. New York: Springer; 2011. pp. 121-164.

Lorenzi H. Árvores brasileiras: manual de identificação e cultivo de plantas arbóreas do Brasil. 4th ed. Nova Odessa: Instituto Plantarum; 2002. 394 p. vol. 1.

Martínez-Cabrera HI, Schenk HJ, Cevallos-Ferriz RS, Jones CS. Integration of vessel traits, wood density, and height in angiosperm shrubs and trees. American Journal of Botany 2011; 98(5): 915-922. http://dx.doi.org/10.3732/ ajb.1000335. PMid:21613189.

Mattheck C, Kubler H. Wood: the internal optimization of trees. 2nd ed. Heidelberg: Springer Verlag; 1997. 131 p. http://dx.doi.org/10.1007/978-3-642-61219-0.

Niklas K. Plant biomechanics: an engineering approach to plant form and function. Chicago: University of Chicago Press; 1992. $622 \mathrm{p}$.

Pavanelli AP, Carvalho ES, Batista NA, Massetti AV, Pimenta JA, Bianchini E. Dinâmica populacional de Astronium graveolens Jacq. (Anacardiaceae) em áreas topograficamente distintas de um fragmento de Floresta Estacional Semidecidual no Norte do Paraná. In: X Congresso de Ecologia do Brasil; 2011; São Lourenço. São Paulo: Sociedade de Ecologia do Brasil Lourenço; 2011. p. 1-2.

Reiterer A, Burgert I, Sinn G, Tschegg S. The radial reinforcement of the wood structure and its implication on mechanical and fracture mechanical properties: a comparison between two tree species. Journal of Materials Science 2002; 37(5): 935-940. http://dx.doi. org/10.1023/A:1014339612423.

Santos CM, Lima IL, Longui EL, Romeiro D, Zanatto ACS, Morais E et al. A densidade básica e características anatômicas variam radialmente na madeira de Astronium graveolens Jacq. (Anacardiaceae). Revista do Instituto Florestal 2011; 23(2): 191-201.

Silva-Luz CL, Pirani JR. Anacardiaceae. In: Jardim Botânico do Rio de Janeiro - JBRJ. Lista de Espécies da Flora do Brasil [online]. Rio de Janeiro; 2013. Available from: http://floradobrasil.jbrj.gov.br/jabot/floradobrasil/FB4385 
Siqueira ACMF, Nogueira JCB. Essências brasileiras e sua conservação genética no Instituto Florestal de São Paulo. Revista do Instituto Florestal 1992; 4(4): 1187.

Tomazello Filho M, Lisi CS, Hansen N, Cury G. Anatomical features of increment zones in different tree species in the State of São Paulo, Brazil. Scientia Forestalis 2004; 66: 46-55.
Tyree MT, Zimmermann MH. Xylem structure and the ascent of sap. New York: Springer; 2002. 283 p. http:// dx.doi.org/10.1007/978-3-662-04931-0.

Woodcock DW. Occurrence of woods with a gradation in vessel diameter across a ring. IAWA Journal 1994; 15(4): 377-385. http://dx.doi.org/10.1163/22941932-90001371. 